\title{
Noble Metals-Based Catalysts for Hydrogen Production via Bioethanol Reforming in a Fluidized Bed Reactor ${ }^{\dagger}$
}

\author{
Concetta Ruocco*, Vincenzo Palma, Marta Cortese and Marco Martino
}

1 Department of Industrial Engineering, University of Salerno, Via Giovanni Paolo II 132, 84084, Fisciano

(SA), Italy; vpalma@unisa.it (V.P.); mcortese@unisa.it (M.C.); mamartino@unisa.it (M.M.)

* Correspondence: cruocco@unisa.it

+ Presented at the 1th International Electronic Conference on Catalysis Sciences, 10-30 November 2020; Available online: https://sciforum.net/conference/ECCS2020

Published: 10 November 2020

\begin{abstract}
In this work, $\mathrm{Pt}-\mathrm{Ni} / \mathrm{CeO}_{2}-\mathrm{SiO}_{2}$ as well as $\mathrm{Ru}-\mathrm{Ni} / \mathrm{CeO}_{2}-\mathrm{SiO}_{2}$ catalysts were obtained at different loadings of the noble metal (in the interval $0-3 \mathrm{wt} \%$ ) and tested for oxidative steam reforming of ethanol. Stability performance was evaluated at $500{ }^{\circ} \mathrm{C}$ for $25 \mathrm{~h}$ under a steam to ethanol ratio of 4 and an oxygen to ethanol ratio of 0.5 . The weight hourly space velocity was fixed to $60 \mathrm{~h}^{-1}$, which is considerably higher than the typical values selected for such process. All the catalyst deactivated with time-on-stream, due to the severe operative conditions selected. However, the highest ethanol conversion (above 95\%) and hydrogen yield (30\%) at the end of the test were recorded over the $2 \mathrm{wt} \% \mathrm{Pt}-10 \mathrm{wt} \% \mathrm{Ni} / \mathrm{CeO}_{2}-\mathrm{SiO}_{2}$ catalyst, which also displayed a limited carbon formation rate $\left(1.5 \times 10^{-6} \mathrm{~g}_{\text {coke }} \cdot \mathrm{g}_{\text {catalyst }}{ }^{-1} \cdot \mathrm{g}_{\text {carbon, fed }}{ }^{-1} \cdot \mathrm{h}^{-1}\right.$, reduced of almost 5 times compared to the samples having a Pt or Ru content of $0.5 \mathrm{wt} \%$ ). Thus, the latter catalyst was identified as a promising candidate for future tests under real bioethanol mixture.
\end{abstract}

Keywords: hydrogen; ethanol; reforming; bimetallic catalyst; stability; coke

\section{Introduction}

The development of sustainable processes for energy generation is one of the most important goal of academic as well as industrial research. In this field, hydrogen conversion in fuel cells is gaining increasing attention: water is the only byproduct and any other pollutant (i.e., $\mathrm{CO}_{2}$ ) is released [1,2]. However, at present, hydrogen production predominantly depends on fossil fuels resources, with methane steam reforming being the most widespread method for $\mathrm{H}_{2}$ generation and nearly half of the world's hydrogen still deriving from natural gas [3]. Thus, in response to the problems of fossil fuels depletion and environmental pollution, the methods of producing hydrogen from biomass have been regarded as potential ways to ensure hydrogen become the fuel of the future. To this end, the catalytic reforming of bioethanol (produced by fermentation of biomass sources) has been proposed as an interesting alternative $[4,5]$.

However, the reaction mechanism is quite complex and several reactions may occur, reducing hydrogen yield and causing carbon deposition on catalysts surface. Thus, the development of active catalysts with high resistance towards deactivation is one of the main issues in this process. To this aim, oxygen co-feeding was reported as a useful tool to promote the oxidation of carbonaceous deposits.

The performance of a large number of catalysts for ethanol reforming has been investigated in the literature: the combination of nickel with reduced amounts of noble metals was proposed to mitigate the coke formation tendency of nickel and limit, at the same time, the price of the final catalyst [6-8]. The choice of reducible support with high surface area was also reported to improve 
the catalyst resistance towards deactivation [9]. In our previous work, highly dispersed $3 \mathrm{wt} \% \mathrm{Pt}-10$ $\mathrm{wt} \% \mathrm{Ni} / \mathrm{CeO}_{2}-\mathrm{SiO}_{2}$ catalysts have been prepared, which displayed high stability during oxidative steam reforming of ethanol [10].

In the present work, the effect of Pt loading on catalyst resistance towards deactivation was investigated and the chance of substituting $\mathrm{Pt}$ by a less expensive metal (i.e., ruthenium) was also discussed. The catalysts were tested under a simulated bioethanol stream (Ethanol:Water $=1: 4)$ by fixing a contact time of $50 \mathrm{~ms}$, much lower than the typical values selected for reforming reactions. Time on stream tests were performed for $25 \mathrm{~h}$ and the performance of the catalysts having various metal loadings were compared in terms of ethanol conversion, hydrogen yield and carbon formation rate.

\section{Materials and Methods}

The catalysts were prepared by the sequential impregnation of the non-noble metal and noble metal on the $\mathrm{CeO}_{2} / \mathrm{SiO}_{2}$ support. The latter material was prepared by adding calcined mesoporous silica gel (provided by Sigma-Aldrich) to a solution of acetic acid/methanol (40/60\% vol.) containing the ceria salt precursor (i.e., Cerium acetylacetonate). Nickel was deposited via the impregnation of $\mathrm{CeO}_{2} / \mathrm{SiO}_{2}$ with an aqueous solution of nickel nitrate hexahydrate while, platinum chloride and ruthenium chloride were selected as precursors of the noble metals. The $\mathrm{CeO}_{2} / \mathrm{SiO}_{2}$ ratio was fixed to 0.3 while nickel content with respect to the ceria mass was equal to $10 \mathrm{wt} \%$; the loading of the noble metal was changed in the interval $0-3 \mathrm{wt} \%$. Thus, the following catalysts were prepared: $\mathrm{Ni} / \mathrm{CeO}_{2}-$ $\mathrm{SiO}_{2}, 0.5 \mathrm{Pt}-\mathrm{Ni} / \mathrm{CeO}_{2}-\mathrm{SiO}_{2}, 1 \mathrm{Pt}-\mathrm{Ni} / \mathrm{CeO}_{2}-\mathrm{SiO}_{2}, 2 \mathrm{Pt}-\mathrm{Ni} / \mathrm{CeO}_{2}-\mathrm{SiO}_{2}, 3 \mathrm{Pt}-\mathrm{Ni} / \mathrm{CeO}_{2}-\mathrm{SiO}_{2}, \quad 0.5 \mathrm{Ru}-\mathrm{Ni} / \mathrm{CeO}_{2}-$ $\mathrm{SiO}_{2}, 1 \mathrm{Ru}-\mathrm{Ni} / \mathrm{CeO}_{2}-\mathrm{SiO}_{2}, 2 \mathrm{Ru}-\mathrm{Ni} / \mathrm{CeO}_{2}-\mathrm{SiO}_{2}, 3 \mathrm{Ru}-\mathrm{Ni} / \mathrm{CeO}_{2}-\mathrm{SiO}_{2}$.

The specific surface area of fresh and spent catalysts was determined via the BET (BrunauerEmmett-Teller) method by $\mathrm{N}_{2}$ adsorption at $-196^{\circ} \mathrm{C}$ (Costech Sorptometer 1040); before the analysis, the samples were degassed at $150^{\circ} \mathrm{C}$ under vacuum.

Temperature programmed reduction measurements (TPR) were performed in the laboratory apparatus described below. Temperature was raised up to $700{ }^{\circ} \mathrm{C}$ under a $5 \% \mathrm{H}_{2} / \mathrm{Ar}$ stream and hydrogen consumption was estimated from the profiles acquired via a Mass Specreometer (supplied by Hiden Analytical).

The carbon content on the spent catalyst was measured in a TA instrument (Q600) via thermogravimetric analysis: $50 \mathrm{Ncm}^{3} \cdot \mathrm{min}^{-1}$ of air was fed in the chamber and temperature was increased up to $1000{ }^{\circ} \mathrm{C}$.

The plant employed for stability tests is made-up of an electrical furnace, where a fluidized bed reactor can be placed. The reactor is filled with 0.6 grams of catalyst and 2.4 grams of $\mathrm{CeO}_{2} / \mathrm{SiO}_{2}$ (acting as filler). Before every test, the loaded sample was reduced for $1 \mathrm{~h}$ at $600{ }^{\circ} \mathrm{C}$ under a $5 \% \mathrm{H}_{2} / \mathrm{Ar}$ stream. The simulated bioethanol mixture, fed at a rate of $31.6 \mathrm{~h}^{-1}$, can be sent to a boiler for vaporization; in the latter thank, argon is also added as diluent. The latter stream, having a volumetric composition of $10 \%$ ethanol, $40 \%$ water and $50 \%$ argon, reaches the reactor through a traced line; 3.6 $\mathrm{Ncm}^{3} \cdot \mathrm{min}^{-1}$ of oxygen are sent to the reactor via an independent line. The weight hourly space velocity (WHSV), referred to the ethanol mass flow rate, was fixed to $60 \mathrm{~h}^{-1}$. The product gas distribution was monitored via a Mass Spectrometer provided by Hiden Analytical. The performance of the catalysts were compared in terms of ethanol conversion $(\mathrm{X})$, hydrogen yield $(\mathrm{Y})$ and carbon formation rate (CFR), based on the results of thermogravimentric analysis on the spent catalysts, which were defined according to Equations (1)-(3), respectively.

$$
\begin{aligned}
& X=\frac{\text { moles }_{\text {ethanol,in }}-\text { moles }_{\text {ethanol,out }}}{\text { moles }_{\text {ethanol,in }}}, \\
& Y=\frac{\text { moles }_{\text {hydrogen,out }}}{6 \cdot \text { moles }_{\text {ethanol, }, \text { }}}, \\
& \text { CFR }=\frac{\text { mass }_{\text {carbon,measured }}}{\text { mass }_{\text {carbon, fed }} \cdot \text { mass }_{\text {catalyst }} \text { hours of test }}{ }^{\prime}
\end{aligned}
$$

\section{Results and Discussion}




\subsection{Characterization of the Fresh Catalysts}

Table 1 summarizes the results of characterization in terms of BET surface area and hydrogen consumption recorded during TPR analysis.

Table 1. Results of fresh catalysts characterization.

\begin{tabular}{cccc}
\hline Sample & BET Area $\left(\mathbf{m}^{\mathbf{2}} \cdot \mathbf{g}^{-\mathbf{1}}\right)$ & $\begin{array}{c}\text { Expected Hydrogen } \\
\text { Uptake } \\
\left(\boldsymbol{\mu} \mathbf{m o l}_{\mathbf{2} 2} \cdot \mathbf{g}_{\text {catalyst }}{ }^{-1}\right)\end{array}$ & $\begin{array}{c}\text { Calculated Hydrogen } \\
\text { Uptake }\left(\mu \mathbf{m o l}_{\mathbf{H}} \cdot \mathbf{g}_{\text {catalyst }}{ }^{-1}\right)\end{array}$ \\
\hline $\mathrm{Ni} / \mathrm{CeO}_{2}-\mathrm{SiO}_{2}$ & 230 & 1704 & 2035 \\
$0.5 \mathrm{Pt}-\mathrm{Ni} / \mathrm{CeO}_{2}-\mathrm{SiO}_{2}$ & 213 & 1755 & 2345 \\
$1 \mathrm{Pt}-\mathrm{Ni} / \mathrm{CeO}_{2}-\mathrm{SiO}_{2}$ & 214 & 1806 & 2777 \\
$2 \mathrm{Pt}-\mathrm{Ni} / \mathrm{CeO}_{2}-\mathrm{SiO}_{2}$ & 226 & 1909 & 2756 \\
$3 \mathrm{Pt}-\mathrm{Ni} / \mathrm{CeO}_{2}-\mathrm{SiO}_{2}$ & 227 & 2011 & 2829 \\
$0.5 \mathrm{Ru}-\mathrm{Ni} / \mathrm{CeO}_{2}-\mathrm{SiO}_{2}$ & 212 & 1803 & 2341 \\
$1 \mathrm{Ru}-\mathrm{Ni} / \mathrm{CeO}_{2}-\mathrm{SiO}_{2}$ & 208 & 1902 & 2586 \\
$2 \mathrm{Ru}-\mathrm{Ni} / \mathrm{CeO}_{2}-\mathrm{SiO}_{2}$ & 210 & 2099 & 2714 \\
$3 \mathrm{Ru}-\mathrm{Ni} / \mathrm{CeO}_{2}-\mathrm{SiO}_{2}$ & 218 & 2297 & 3095 \\
\hline
\end{tabular}

Due to the choice of silica as support, all the prepared catalysts displayed surface areas higher than $200 \mathrm{~m}^{2} \cdot \mathrm{g}^{-1}$ and only a slight reduction of the final area was recorded upon active species deposition. The employment of materials with high surface area was shown to be a useful tool in order to minimize active phase sintering and improve the activity as well as the stability of the final catalyst [11].

The comparison between the expected and calculated hydrogen uptake revealed that, for all the catalysts investigated in this work, the hydrogen consumption exceeded the theoretical values. These results, enhanced by the addition of the noble metals, can be ascribed to the occurrence of spillover phenomena: active metals such as $\mathrm{Ni}, \mathrm{Pt}, \mathrm{Pd}, \mathrm{Ru}, \mathrm{Rh}$ have been reported to significantly lower the reduction temperature of cerium oxide. Thus, hydrogen adsorbs onto the metal phase in a dissociative way and the resulting atomic hydrogen can be transported to the oxide support [12]. As a consequence, the calculated uptake was enhanced with respect to the values calculated only accounting for the active metals. Such easier hydrogen transfer trough the catalyst was shown to improve the reforming activity [13].

\subsection{Stability Evaluation duriong Oxidative Steam Reforming of Ethanol}

The trend of ethanol conversion and hydrogen yield as a function of time-on-stream over the various catalyst is reported in Figure 1.

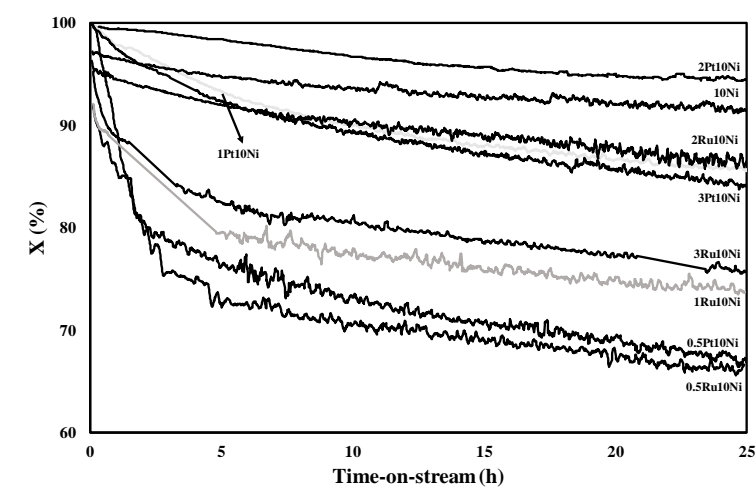

(a)

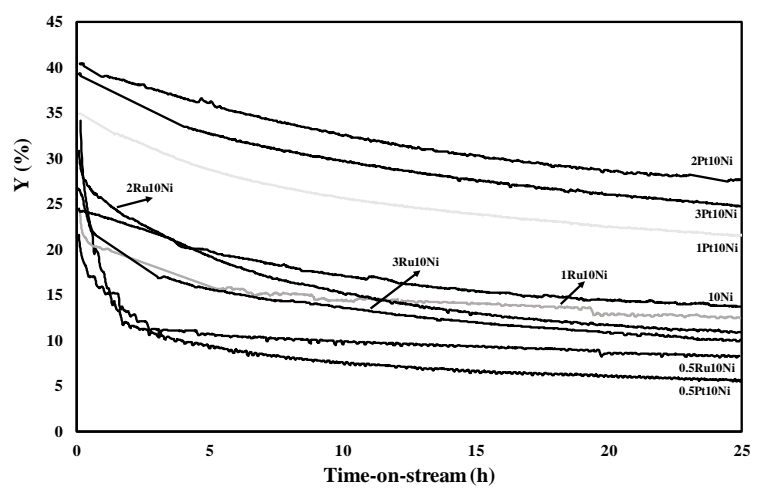

(b)

Figure 1. (a) Ethanol conversion; (b) hydrogen yield over Ni-based catalyst as a function of time-onstream; $\mathrm{P}=1 \mathrm{~atm}, \mathrm{~T}=500{ }^{\circ} \mathrm{C} ; \mathrm{C}_{2} \mathrm{H}_{5} \mathrm{OH}: \mathrm{H}_{2} \mathrm{O}: \mathrm{O}_{2}: \mathrm{Ar}=1: 4: 0.5: 4.5, \mathrm{WHSV}=60 \mathrm{~h}^{-1}$.

Both ethanol conversion and hydrogen yield decreased with time-on-stream, indicating that deactivation phenomena occurred, irrespective of the chosen noble metal and its loading. However, 
the lowest activity loss was recorded over the $2 \mathrm{Pt}-10 \mathrm{Ni} / \mathrm{CeO}_{2}-\mathrm{SiO}_{2}$ catalyst, which displayed a variation in ethanol conversion from $100 \%$ to $95 \%$ and a reduction in hydrogen yield from $40 \%$ to $30 \%$ during $25 \mathrm{~h}$ of test. The monometallic catalyst reached a quite high conversion at the end of the test, with final values increased with respect to the Pt-Ni as well as Ru-Ni formulations. Conversely, hydrogen yield was reduced in comparison to the $1 \mathrm{Pt}-\mathrm{Ni}, 2 \mathrm{Pt}-\mathrm{Ni}$ and $3 \mathrm{Pt}-\mathrm{Ni}$ catalysts, which demonstrated that the noble metal has a crucial role in promoting the pathways involved in $\mathrm{H}_{2}$ production. However, the samples containing $0.5 \mathrm{wt} \%$ of $\mathrm{Pt}$ or Ru displayed very poor stability. In addition, under the selected operative conditions, ruthenium addition on the $\mathrm{Ni} / \mathrm{CeO}_{2}-\mathrm{SiO}_{2}$ was not capable to improve the catalyst resistance towards deactivation. From these results, it is possible to conclude that low amounts of noble metals are even detrimental in terms of stability. In addition, for the Pt-based series, the stability performance increased with the Pt loading up to $2 \mathrm{wt} \%$; a further growth in the platinum content did not allow any benefit in terms of resistance towards deactivation.

\subsection{Characterization of the Spent Catalysts}

The catalysts, after the stability tests described in Figure 1, were characterized to evaluate the effect of time on stream on their specific surface areas as well as the extent of carbon deposition. The BET area of the spent catalysts and the relative carbon formation rate (defined in Equation (3)) are listed in Table 2.

Table 2. Results of spent catalysts characterization.

\begin{tabular}{|c|c|c|}
\hline Sample & BET Area $\left(\mathrm{m}^{2} \cdot \mathrm{g}^{-1}\right)$ & Carbon Formation Rate $\left(\mathrm{g}_{\text {coke }} \cdot \mathrm{g}_{\text {carbon, fed }}{ }^{-1} \cdot \mathrm{g}_{\text {catalyst }}{ }^{-1} \cdot \mathbf{h}^{-1}\right)$ \\
\hline $\mathrm{Ni} / \mathrm{CeO}_{2}-\mathrm{SiO}_{2}$ & 182 & $3.9 \times 10^{-6}$ \\
\hline $0.5 \mathrm{Pt}-\mathrm{Ni} / \mathrm{CeO}_{2}-\mathrm{SiO}_{2}$ & 145 & $8.4 \times 10^{-6}$ \\
\hline $1 \mathrm{Pt}-\mathrm{Ni} / \mathrm{CeO}_{2}-\mathrm{SiO}_{2}$ & 179 & $2.4 \times 10^{-6}$ \\
\hline $2 \mathrm{Pt}-\mathrm{Ni} / \mathrm{CeO}_{2}-\mathrm{SiO}_{2}$ & 191 & $1.5 \times 10^{-6}$ \\
\hline $3 \mathrm{Pt}-\mathrm{Ni} / \mathrm{CeO}_{2}-\mathrm{SiO}_{2}$ & 186 & $2 \times 10^{-6}$ \\
\hline $0.5 \mathrm{Ru}-\mathrm{Ni} / \mathrm{CeO}_{2}-\mathrm{SiO}_{2}$ & 142 & $7.9 \times 10^{-6}$ \\
\hline $1 \mathrm{Ru}-\mathrm{Ni} / \mathrm{CeO}_{2}-\mathrm{SiO}_{2}$ & 143 & $5.1 \times 10^{-6}$ \\
\hline $2 \mathrm{Ru}-\mathrm{Ni} / \mathrm{CeO}_{2}-\mathrm{SiO}_{2}$ & 145 & $5.8 \times 10^{-6}$ \\
\hline $3 \mathrm{Ru}-\mathrm{Ni} / \mathrm{CeO}_{2}-\mathrm{SiO}_{2}$ & 149 & $6.3 \times 10^{-6}$ \\
\hline
\end{tabular}

The Ru-based catalysts displayed a more pronounced surface area decrease compared to the Pt$\mathrm{Ni} / \mathrm{CeO}_{2}-\mathrm{SiO}_{2}$ sample. In addition, the carbon formation rate grew from $5.1 \times 10^{-6} 6$ of the $1 \mathrm{wt} \% \mathrm{Ru}$ sample to $7.9 \times 10^{-6}$ of the $0.5 \mathrm{Ru}-\mathrm{Ni} \mathrm{g}_{\text {coke }} \cdot \mathrm{g}_{\text {carbon,fed }}{ }^{-1} \cdot \mathrm{g}_{\text {catalyst }}{ }^{-1} \cdot \mathrm{h}^{-1}$. These results are in line with the marked deactivation observed over the latter catalysts, attested by the quite high rate of coke formation: carbon deposits may occlude the catalyst pores, thus limiting the access of reactants to the catalyst surface [14]. For the most stable sample $\left(2 \mathrm{Pt}-\mathrm{Ni} / \mathrm{CeO}_{2}-\mathrm{SiO}_{2}\right)$, the surface area reduction was only of $15 \%$ while CFR was as low as $1.5 \times 10^{-6} \mathrm{~g}_{\text {coke }} \cdot \mathrm{g}_{\text {carbon,fed }}{ }^{-1} \cdot \mathrm{g}_{\text {catalyst }}{ }^{-1} \cdot \mathrm{h}^{-1}$. Moreover, the Pt-catalyst having a noble metal content of $0.5 \mathrm{wt} \%$ displayed the highest carbon formation rate among the tested catalysts, which is in line with the pronounced decrease of ethanol conversion and hydrogen yield observed in Figure 1. The results shown in Table 2 demonstrated that catalyst deactivation was mainly caused by carbon deposition and that the $2 \mathrm{Pt}-10 \mathrm{Ni} / \mathrm{CeO}_{2}-\mathrm{SiO}_{2}$ catalyst was the less susceptible to deactivation induced by coke.

\section{Conclusions}

The Pt-Ni and $\mathrm{Ru}-\mathrm{Ni} / \mathrm{CeO}_{2}-\mathrm{SiO}_{2}$ catalysts with various platinum and ruthenium loading $(0,1,2$, $3 \mathrm{wt} \%$ ) were prepared by sequential wet impregnation and investigated towards oxidative steam reforming of ethanol in terms of ethanol conversion, hydrogen yield and carbon formation rate. The results of stability tests showed that the severe operative condition selected (high space velocity) caused a decrease in the performance of all the catalysts with time-on-stream. However, the catalyst resistance towards deactivation increased with the noble metal up to $2 \mathrm{wt} \%$ while, a further growth 
in $\mathrm{Pt}$ as well as Ru content did not assess any benefit. The Pt-based samples were found to be more stable than the $\mathrm{Ru}-\mathrm{Ni} / \mathrm{CeO}_{2}-\mathrm{SiO}_{2}$ catalyst, which underwent a more pronounced surface area decrease and displayed quite high carbon formation rates. After $25 \mathrm{~h}$ of test, the $2 \mathrm{Pt}-10 \mathrm{Ni} / \mathrm{CeO}_{2}-\mathrm{SiO}_{2}$ catalyst displayed $95 \%$ of ethanol conversion and $30 \%$ of hydrogen yield. Thus, the latter catalyst was shown to be an effective sample to improve stability and reduce carbon deposition during oxidative steam reforming of ethanol.

Author Contributions: Conceptualization, V.P. and C.R.; methodology, M.C.; formal analysis, V.P.; investigation, C.R. and M.M.; resources, M.C.; data curation, M.M. and M.C.; writing-original draft preparation, C.R. and M.C.; writing - review and editing, V.P. and M.M.; visualization, C.R., M.C. and M.M.; supervision, V.P.; project administration, V.P.; funding acquisition, V.P.

Funding: This work has received funding from the European Union's Horizon 2020 research and innovation programme under the Marie Skłodowska-Curie grant agreement No 734561.

Conflicts of Interest: The authors declare no conflict of interest.

\section{References}

1. Luo, L.; Zhang, T.; Zhang, X.; Yun, R.; Lin, Y.; Zhang, B.; Xiang, X. Enhanced Hydrogen Production from Ethanol Photoreforming by Site-Specific Deposition of $\mathrm{Au}$ on $\mathrm{Cu}_{2} \mathrm{O} / \mathrm{TiO}_{2}$ pn Junction. Catalysts 2020, 10, 539.

2. Łamacz, A.; Jagódka, P.; Stawowy, M.; Matus, K. Dry Reforming of Methane over CNT-Supported CeZrOz, $\mathrm{Ni}$ and $\mathrm{Ni}-\mathrm{CeZrO}_{2}$ Catalysts. Catalysts 2020, 10, 741.

3. Chen, K.; Zhao, Y.; Zhang, W.; Feng, D.; Sun, S. The intrinsic kinetics of methane steam reforming over a nickel-based catalyst in a micro fluidized bed reaction system. Int. J. Hydrog. Energ. 2020, 45, 1615-1628.

4. Gabriel Rullo, P.; Costa-Castelló, R.; Roda, V.; Feroldi, D. Energy Management Strategy for a Bioethanol Isolated Hybrid System: Simulations and Experiments. Energies 2018, 11, 1362.

5. Palma, V.; Ruocco, C.; Cortese, M.; Martino, M. Bioalcohol Reforming: An Overview of the Recent Advances for the Enhancement of Catalyst Stability. Catalysts 2020, 10, 665.

6. Mondal, T.; Pant, K.K.; Dalai, A.K. Oxidative and non-oxidative steam reforming of crude bio-ethanol for hydrogen production over Rh promoted $\mathrm{Ni} / \mathrm{CeO}_{2}-\mathrm{ZrO}_{2}$ catalyst. Appl. Catal. A: Gen. 2015, 499, 19-31.

7. Palma, V.; Ruocco, C.; Meloni, E.; Gallucci, F.; Ricca, A. Enhancing Pt-Ni/ $/ \mathrm{CeO}_{2}$ performances for ethanol reforming by catalyst supporting on high surface silica. Catal. Today 2018, 307, 175-188.

8. Soyal-Baltacıoğlu, F.; Aksoylu, A.E.; Önsan, Z.I. Steam reforming of ethanol over Pt-Ni Catalysts. Catal. Today 2008, 138, 183-186.

9. Palma, V.; Ruocco, C.; Meloni, E.; Ricca, A. Renewable Hydrogen from Ethanol Reforming over $\mathrm{CeO}_{2}-\mathrm{SiO}_{2}$ Based Catalysts. Catalysts 2017, 7, 226.

10. Ruocco, C.; Palma, V.; Ricca, A. Hydrogen production by oxidative reforming of ethanol in a fluidized bed reactor using a PtNi/ $\mathrm{CeO}_{2} \mathrm{SiO}_{2}$ catalyst. Int. J. Hydrog. Energ. 2019, 44, 12661-12670.

11. Laosiripojana, N.; Assabumrungrat, S. Catalytic dry reforming of methane over high surface area ceria. Appl. Cat. B: Environ. 2005, 60, 107-116.

12. Sharma, V.; Crozier, P.A.; Sharma, R.; Adams, J.B. Direct observation of hydrogen spillover in Ni-loaded Pr-doped ceria. Catal. Today 2012, 180, 2-8.

13. Fujimoto, K. Spillover of Hydrogen on Carbon and its Role in Catalytic Hydrocarbon Reforming. J. Japan Pet. Ins. 1984, 27, 463-471.

14. Argyle, M.; Bartholomew, C. Heterogeneous Catalyst Deactivation and Regeneration: A Review. Catalysts 2015, 5, 145 .

Publisher's Note: MDPI stays neutral with regard to jurisdictional claims in published maps and institutional affiliations.

(C) 2020 by the authors. Submitted for possible open access publication under the terms and conditions of the Creative Commons Attribution (CC BY) license (http://creativecommons.org/licenses/by/4.0/). 